\title{
Anti-Leprosy Work in the Punjab
}

Work done from March, 1931 to December, 1934.

$$
\text { S. S. JAIKARIA. }
$$

I

N January, 1925, His Excellency the Viceroy constituted an Indian Branch (Indian Council) of the British Empire Leprosy Relief Association with a view to inaugurating an active campaign for the eradication of this terrible malady from India. At His Excellency's instance the then Governor of the Punjab constituted a Provincial Branch of the Association. A Technical Committee was then appointed by the Local Government to deal with the problem and to suggest practical measures from time to time for stamping out leprosy from the Province.

With this object in view a whole time Leprosy Officer, Dr. S. S. Jaikaria, M.B., B.S., was appointed in March 1931. to collect the necessary material and formulate definite proposals. He commenced the work in Kangra district, under the auspices of the British Empire Leprosy Relief Association, Punjab Branch of which the Inspector General of Civil Hospitals, Punjab, is the President and the Director of Public Health, Punjab, the Honorary Secretary.

The work done from March 1st, 1931 up to the 31st December, 1934, may be summarized under the following heads :

(1) Surveys.

(2) Training of doctors.

(3) Establishing treatment centres

\section{SuRveys.}

In Kangra district, an area covering 3,382.07 sq. miles constituting four tahsils (Palampur, Kangra, Dehra Gopipur and Kulu) out of seven, was surveyed, in a systematic manner, i.e., by a house to house and village to village survey, by P.T.S. Method-a method in which propaganda treatment and survey go hand in hand. In all 2,983 villages and sub-villages, with a population of 873,237 were surveyed, out of which 453 villages (15.10 per cent.) furnished 1,005 leprosy cases (males 790 and females 215) in different stages of the disease. Of these 628 cases were infectious and 377 non-infectious. There were 522 cases of N1, N2 and C1 types which are easily amenable to treatment, and active treatment along with careful observation would result in saving so many lives and reducing the sources of infection. The figures revealed by this survey were six times the 1931 
census figures because only such advanced cases as are evident to the lay enumerators were returned in the census.

In Lahore district, an area covering 731 sq. miles, consisting of Lahore and Baghbanpura Municipalities and Lahore tahsil with 372 villages with a population of 393,004, was systematically surveyed by the P.T.S. method. Three villages and seven places in Lahore municipality furnished 22 leprosy cases (males 20 and females 2) in different stages of the disease. Of these, 16 were non-infectious and six infectious.

It may be of interest to note that in the area surveyed no cases had been hitherto reported, but this survey revealed as many as 22 lepers.

In Rawalpindi district, an area covering 258.19 sq. miles, consisting of tahsil Murree, was surveyed in a systematic way by the P.T.S. method. Forty-one villages out of 226 furnished 102 leprosy cases (males 71 and females 31) in different stages of the disease. Of these, 63 were noninfectious and 39 infectious.

Besides these systematic surveys the Provincial Leprosy Officer also toured in the districts of Multan, Jullundur, Karnal and Ludhiana, in which he detected many leprosy cases and established local clinics.

\section{Training OF Doctors.}

The number of doctors of this province so far trained in leprosy work at Calcutta and by the Provincial Leprosy Officer is 127. In addition, lectures and demonstrations on leprosy were given to the Final Year Students and Post Graduate Class of the King Edward Medical College, Lahore, Medical School, Amritsar, and the Women's Christian Medical College, Ludhiana, by the Provincial Leprosy Officer. Thirty-four treatment centres were started in the districts of Kangra, Jullundur, Ludhiana, Karnal and Rawalpindi. All the medical men in charge of these centres have been trained in up-to-date methods of leprosy diagnosis, treatment and prevention and their dispensaries have been equipped with anti-leprosy drugs. The working of the five Leper Homes in the Punjab has been overhauled and treatment brought up-to-date and rendered more helpful in the prevention of the spread of leprosy.

\section{PROPAGANDA.}

All the schoolboys were examined and extensive propaganda was carried out in the majority of the villages and schools of the areas surveyed, by magic lantern shows, 
wall chart lectures, by demonstrations of cases detected during the examination parades, and by initiating free discussions on different aspects of the disease. Lastly, booklets, pamphlets and leaflets on leprosy in Urdu and Hindi were distributed free of charge.

Wherever cases of leprosy were found the dangers of the disease were explained to the patients themselves, to their near relations, and to the village people generally as well as to the village officials by the Provincial Leprosy Officer, who also issued subsequently instructions to the village officials to ensure that the persons suffering from leprosy regularly attended the centres for treatment. Infectious cases of leprosy were isolated in houses or huts outside the villages; where house or village isolation was not possible, they were induced to go to Leper Homes. 